\title{
Kecerdasan moral ditinjau dari perbedaan pola asuh pada siswa SMA
} Yulinda S Manurung', Antoneta Fransiska B. Lete ${ }^{2^{*}}$, Mega Y A Nababan ${ }^{3}$, Abigail C Ampow ${ }^{4}$ Fakultas Psikologi Universitas Prima Indonesia, Medan

\begin{tabular}{l}
\hline Info Artikel \\
\hline Sejarah Artikel: \\
Diterima \\
27 November 2019 \\
Direview \\
24 Februari 2020 \\
Disetujui \\
10 September 2020 \\
Dipublikasikan \\
28 September 2020 \\
\hline Keywords: \\
Moral Intelligence, \\
Parenting style, \\
Students
\end{tabular}

\author{
Abstrak \\ Objektif: Saat ini banyak peserta didik kurang memperlihatkan perilaku yang baik \\ berhubungan dengan kecerdasan moral. Salah satu faktor yang memengaruhi \\ kecerdasan moral adalah pola asuh orang tua. Tujuan penelitian ini yaitu untuk \\ melihat hubungan antara pola asuh demokratis, otoriter dan permisif terhadap \\ kecerdasan moral.
}

Metode: Subyek penelitian sebanyak 177 siswa SMA Cahaya Medan dengan metode proportionate stratified random sampling. Data penelitian disatukan menggunakan skala kecerdasan moral dan skala pola asuh. Data dianalisis dengan memakai korelasi analisis regresi linear berganda melalui bantuan SPSS 23 for Windows.

Temuan: Hasil penelitian menunjukkan bahwa hubungan yang positif antara pola asuh demokratis dengan kecerdasan moral dengan nilai sig. $0.040(p<0.05)$, pola asuh otoriter dan kecerdasan moral dengan nilai sig. $0.167(p>0.05)$, pola asuh permisif dengan kecerdasan moral dengan nilai sig. $0.570(p>0.05)$. Uji asumsi terdiri dari uji normalitas, uji multikolinearitas, uji autokorelasi, uji heteroskedastisitas. Hasil penelitian memperlihatkan bahwa sumbangan efektif pola asuh terhadap kecerdasan moral sebesar 2,7\%, selebihnya 97,3\% dipengaruhi oleh faktor lain yang tidak diteliti.

Kesimpulan: Hipotesis penelitian diterima

\section{Moral Intelligence Judging from the Different Parenting in High School Students}

Objectives: At present many students lack good behavior related to moral intelligence. One of the factors that influence moral intelligence is parenting. The purpose of this study is to look at the relationship between democratic, authoritarian and permissive parenting to moral intelligence.

Method: The research subjects were 177 students of Medan Light High School with proportionate stratified random sampling method. The research data were put together using a scale of moral intelligence and parenting scale. . Data were analyzed using multiple linear regression analysis correlation through SPSS 23 for Windows.

Findings: The results showed that found a positive relationship between democratic parenting with moral intelligence with sig. 0.040 ( $p<0.05)$, authoritarian parenting and moral intelligence with sig. 0.167 ( $p>0.05)$, permissive parenting with moral intelligence with sig. 0.570 ( $p>0.05$ ). The assumption test consists of normality test, multicollinearity test, autocorrelation test, heteroscedasticity test The results showed that the effective contribution of parenting to moral intelligence was $2.7 \%$, the rest $97.3 \%$ was influenced by other factors not examined.

Conclusions: Research hypothesis is accepted,

\footnotetext{
*Alamat korespondensi:

Jl.Sekip,Simpang Sei Sikambing,Sei Putih Tim I, Kec. Medan petisah,Kota medan, Sumatera Utara 20I I I bellaprimal7@gmail.com
} 


\section{Pendahuluan}

Manusia adalah makhluk yang selalu bertumbuh dan berkembang. Pertumbuhan dan perkembangan manusia selalu melewati masa kanak-kanak menuju masa remaja dan dewasa. Fase remaja merupakan fase pelepasan dan penerimaan dari masa kanak-kanak menuju masa dewasa. Fase ini tampak dari perkembangan dan perubahan fisik, bilogis, kognitif dan sosio emosional (Jannah, Yacob \& Julianto (2017). Fase ini terdiri dari dua periode yakni awal (dari usia I0-I3 tahun) dan akhir (dari usia 18-22 tahun) (Santrock, 20I I).

Fase remaja biasanya ditandai dengan pelbagai macam perubahan; baik secara fisik maupun mental. Secara fisik, seorang remaja bertumbuh menjadi orang yang semakin tinggi, badan semakin berotot, dan lain sebagainya. Secara mental, terkadang emosi kurang stabil, ingin menjadi pusat perhatian, berkarakter superior terhadap yang lain, sering membuat keonaran yang menuntut orang dewasa terlibat di dalamanya. Walaupun demikian, ada sebagaian remaja yang merasa mampu mencari solusi atas masalah mereka, sehingga mereka tidak mau melibatkan orang tua.

Usia remaja adalah usia seorang individu memperoleh pendidikan formal di bangku Sekolah Menengah Pertama (SMP) dan Sekolah Menengah Atas (SMA). Pendidikan adalah salah satu sarana yang diatur secara sistematis didasari pada kesadaran individu untuk mengembangkan potensi dirinya dalam suasana belajarmengajar. Potensi itu dapat dikembangkan dengan, bimbingan, latihan, yang terus menerus. Salah satu tujuan pendidikan di Indonesia adalah mencerdaskan kehidupan bangsa. Sekolah baik SMP maupun SMA adalah wadah pendidikan yang mewujud nyatakan tujuan pendidikan di Indonesia yakni mencerdaskan kehidupan bangsa. Dalam proses tersebut tentunya melibatkan kerjasama antara pihak sekolah, orangtua dan peserta didik itu sendiri. Hal penting lainnya juga yang harus diperhatikan dalam menunjang kecerdasan anak bangsa adalah perilaku baik yang dimiliki oleh individu.

Pendidikan Indonesia saat ini mengalami degradasi nilai. Ada beberapa siswa yang mengenyam pendidikan di Sekolah Menengah Atas kurang memperhatikan perilaku hidup yang baik. Sebagai contoh, seorang siswa berinisial AA melawan gurunya ketika ditegur saat merokok di kelas. Peristiwa tersebut terjadi pada tanggal 02 Februari 2019. Bermula saat sang guru hendak mengajar tetapi tidak mendapati siswanya di ruangan kelas. Kemudian guru tersebut mencari siswa di luar sekolah dan mendapati jika seluruh siswanya berada di salah satu warung kopi yang berada di dekat lokasi sekolah. Kemudian ia peringatkan agar seluruh siswa segera kembali ke sekolah karena waktu belajar sudah mulai. Namun, upaya sang guru membuat AA marah dan membuat kegaduhan dengan merokok di kelas, menggedor bangku ruangan kelas, membuang buku materi ajar milik guru tersebut (m.merdeka.com-diki, I0 Februari 2019).

Tindakan kriminal lainnya terjadi di Jakarta Barat. Kasus ini menimpa Adam Ilham, yang dianiaya oleh geng motor hingga meninggal dunia. Perilaku yang tidak terpuji ini bermula saat Adam Ilham dan tiga temannya mampir di tempat pengisian bahan bakar umum tanggal 20 Januari 2019, pukul 04.00. Usai pengisian bahan bakar, mereka melewati Gang Thalib, Krukut - Tamansari. Kejadian ini bermula ketika korban dan rekannya mengejek anggota geng motor yang sedang berkumpul disitu. Tak lama kemudian, mereka dikejar oleha nggota geng motor. Ilham terjatuh di jalan Raya Tanah Sereal Raya dan dibacok secara bergantian dengan celurit. Ilham pun meninggal dunia. Kejadian kriminal lainnya menimpa Ahmad Al Fandri yang tewas dibacok oleh geng motor di kawasan Tanjung Duren - Jakarta Barat. Kasus bermula saat gerombolan geng motor melewati Jalan Tubagus Angke bersama teman-temannya mengendarai sepeda motor.

Hal yang sama terjadi di SMA Cahaya Medan, dimana salah seorang siswa berinisial B tidak mengumpulkan tugas, karena ia tidak mengerjakan tugasnya diwaktu yang telah diberikan. Ketika ditanya alasan mengapa ia tidak mengumpulkan tugas, B menjawab dengan santai bahwa ia tidak tahu cara menyelesaikannya. Hampir semua tugas yang diberikan oleh setiap guru mata pelajaran tidak dikerjakan oleh si B dengan alasan tidak tahu cara menyelesaikannya. Fenomena lain yang dapat ditemukan adalah seorang siswa yang berinisial $\mathbf{Z}$ tidak membayar biaya pendidikannya selama satu bulan. Ketika ditanya oleh wali kelas "mengapa tidak membayar uang sekolah selama satu bulan?" dengan santai Z menjawab "uangnya sudah tidak ada bu, saya sudah pergunakan untuk kebutuhan yang lain.” Dari kasus dan fenomena di atas terlihat banyaknya remaja yang tidak memiliki kecerdasan moral yang optimal.

Di sisi lain terdapat seorang siswa berinisial GT menunjukkan perilaku yang cukup baik. Hal tersebut dapat peneliti lihat ketika berbaris di depan kelas, saat jam istrahat berlangsung, ketika Kegiatan Belajar mengajar berlangsung, GT selalu menunjukkan sikap yang baik, bertutur kata yang sopan, tidak pernah terlambat datang ke sekolah dan mengumpul tugas tepat pada waktunya dan juga GT disukai oleh teman-temannya. Setelah peneliti melakukan wawancara dengannya, peneliti dapat menyimpulkan bahwa GT mendapatkan pola asuhan yang baik dari orang tuanya. Orang tuanya memberi kebebasan namun tetap mengawasi dan 
memberikan himbauan yang baik pada anaknya. Dari fenomena-fenomena yang ada, peneliti melihat bahwa pola asuh berpengaruh dalam perkembangan kecerdasan moral seseorang.

Kecerdasan moral merupakan kecakapan individu untuk membedakan hal yang baik dan buruk. Kecerdasan ini mencakup kemampuan untuk memahami pilihan-pilihan yang berbeda, memiliki rasa empati, memperjuangkan keadilan, dan menunjukkan kasih sayang dan rasa hormat terhadap orang lain (Borba, dalam Adiyanti dan sofia, 20I4). Lennick dan Kiel (Zikri, 20I5) mengemukakan empat aspek kecerdasan moral : Pertama, integritas (integrity) dalam arti pribadi yang jujur, integrer, tidak mudah terpengaruh oleh faktor eksternal melainkan pribadi yang teguh pada prinsip hidup moral. Kecerdasan ini ditandai dengan konsisten pada prinsip, nilai dan keyakinan (acting consistenly with principles, values and beliefs), berkata yang sebenarnya (telling the truth), berpegang teguh pada kebenaran (Standing up for what is right), memenuhi janji (keeping promises). Kedua, tanggung jawab (responsibility). Tanggung jawab terhadap pilihan pribadinya, (taking Responsibility for personal choices), mengakui kesalahan dan kegagalan (admitting mistakes and failure), berkomitmen untuk melayani sesama (embracing responsibility for serving). Ketiga, perasaan iba (compassion) yang ditunjukkan dengan sikap peduli terhadap sesame, menghormati orang lain, peduli ketika ia sedang membutuhkan. Keempat, pemaaf (forgiveness) dapat dilihat dari sikap menerima kesalahan diri sendiri (letting go of our own mistakes) dan rela memberi maaf kepada orang lain dengan menerima kesalahan yang telahdiperbuat.

Kecerdasan moral sebenarnya dapat dipelajari dan bisa diterapkan sejak balita. Sekolah juga tidak boleh lepas dari peran ini, karena seorang anak yang sudah duduk di bangku sekolah akan menghabiskan sebagian waktunya di sekolah, berinteraksi dengan guru-guru yang berperan sebagai pengajar dan pendidik dan teman-teman yang dapat memberikan pengaruh positif dan juga negatif. Dalam suatu lembaga pendidikan, sekolah merupakan lembaga pendidikan formal yang mempunyai program yang sistemik dalam melaksanakan bimbingan, pengajaran, dan latihan kepada siswa agar mereka berkembang sesuai potensinya.

Saat ini, timbul berbagai macam persoalan dalam masyarakat yang dibuat oleh anak-anak. Hal ini menuntut pendampingan yang luar biasa dari orang tua. Pendampingan orang tua mestinya tidak sekedar membuat anak-anak mereka mampu berpikir dengan baik, tapi harus mengajarkan kepada mereka bagaimana berpikir baik dan bertindak baik; berpikir kritis, bertindak bijak, berlaku santun dan bermoralkan kesopanan yang berpedoman pada norma-norma moral yang berlaku. Apabila ditemukan bahwa ada sebagian anak yang bertindak tidak sesuai dengan kaidah-kaidah moral maka sebenarnya perkembangan moralnya agak terganggu. kita tahu bahwa karakter seseorang dapat dilihat dari tindakan bukan hanya dari pemikiran. Sebab seringkali ada ketidaksesuaian antara apa yang dipikirkan dan apa yang diperbuat.

Orang tua tentu mendambakan kecerdasan moral anaknya. Kecerdasan moral anak pasti akan memberikan harapan bagi orang tuanya. Harapan orang tuanya agar supaya anaknya tidak hanya mampu berpikir benar tapi juga bertindak benar. Melalui pola asuh yang benar, para orang tua berharap agar karakter kecerdasan moral tumbuh menjadi perilaku hidup moral yang baik. Cara terbaik mengembangkan kemampuan moral anak merupakan langkah paling tepat melindungi kehidupannya sekarang dan selamanya, membangun kecerdasan moral akan mengajarkan bagaimana cara mengembangkan kemampuan anak tersebut (Borba, 2008)

Pola asuh dari orang tua dapat mempengaruhi kecerdasan moral seorang anak. Pola asuh yang baik akan berpengaruh pada perkembangan kecerdasan moral seorang anak dan sebaliknya pola asuh yang buruk berpengaruh pula pada kecerdasan moral anak. Syaiful (20l4) mengatakan bahwa pola asuh orang tua dalam keluarga biasanya merupakan gabungan dari ketiga unsur penting yaitu pola asuh, orangtua, keluarga.

Menurut Hurlock (dalam Ayu, 2016) pola asuh merupakan metode yang dipakai orangtua dalam membesarkan anak. Pola asuh terbagi menjadi tiga jenis yaitu demokratis, otoriter dan permisif. Pengasuhan demokratis merupakan salah satu cara pemeliharaan atau pola asuh orang tua yang memperlihatkan kontrol ekstra ketat terhadap perangai anak, namun orang tua juga berjiwa responsive, memperhitungkan dan menghormati pendapat, pendirian, serta melibatkan anak ketika mengambil sebuah keputusan. Maka dari itu pola asuh demokratis, dilakukan dengan adanya kontrol dari orangtua terhadap anak tetapi tetap memperhitungkan kebebasan anak sebagai individu, penentuan tuntutan yang bersifat rasional, fleksibel, memprioritaskan disiplin anak. Pola asuh otoriter merupakan bentuk pengasuhan dimana orang tua menentukan dan menuntut anak untuk menuruti instruksi orang tua. Bagian pola asuh otoriter, yaitu: kontribusi disiplin, komunikasi, pemenuhan keperluan, ideology terhadap remaja. Pola asuh permisif yaitu bentuk pengasuhan yang dibagi manjadi dua bentuk, yaitu pengasuhan permissive - indulgent dimana orang tua sangat terlibat dalam kehidupan anaknya, tetapi menetapkan sedikit batas atau kendali atas 
mereka dan pengasuhan permissive-indifferent dimana orang tua sangat tidak terlibat dalam kehidupan anak. Aspek-aspek pola asuh permisif melingkupi kontrol terhadap anak minim yaitu tidak adanya pencerahan perilaku anak sesuai dengan norma masyarakat, tidak menempatkan perhatian dengan siapa saja anak bergaul, pengabaian keputusan, orang tua bersifat masa bodoh mengenai ketidakpedulian terhadap anak, pendidikan bersifat bebas tentang kebebasan anak untuk memilih sekolah dengan keinginan anak, tidak adanya nasehat disaat anak melakukan kesalahan, kurang memperhatikan pendidikan moral dan agama.

Rottie dan Karundeng (2016) dalam penelitian mereka menemukan adanya relasi positif antara pola asuh orang tua dan kecerdasan moral anak. Fokus penelitian mereka pada anak usia 12-15 tahun di SMP Negeri I Tabukan Selatan Kabupaten Kepulauan Sangihe. Penelitian yang sama dilakukan oleh Ahsan Susmarini, Anitasari (2014) pada anak usia prasekolah (4-5) tahun di TK Mutiara Indonesia Kedungkandang Malang. Dari hasil penelitian tersebut, ia mnemukan relasi positif antara pola asuh orang tua dengan kecerdasan moral anak. Pangestu, Fadillah, Halida (2016) dengan focus penelitian pada anak usia 5-6 tahun, menemukan hasil yang sama bahwa pola asuh orang tua yang positif berdampak pada kecerdasan moral anak. Dari beberapa hasil penelitian ini menegaskan bahwa pola asuh orang tua yang baik akan berpengaruh positif pada perkembangan kecerdasan moral anak.

Dengan melihat fenomena saat ini yang menunjukkan bahwa banyak remaja yang kurang memperlihatkan perilaku yang baik maka penelitian ini bertujuan untuk melihat hubungan antara pola asuh demokratis, otoriter dan permisif terhadap kecerdasan moral. Manfaat penelitian diharapkan dapat memperluas kajian ilmu psikologi khususnya dalam bidang psikologi pendidikan, juga sebagai sumbangan pemikiran bahwa kecerdasan moral anak berpengaruh dengan bagaimana pola asuh yang diberikan oleh orang tua terhadap anaknya.

\section{Metode}

Pola asuh adalah sebagai variabel bebas yang digunakan dan Kecerdasan Moral merupakan variabel terikat. Penelitian ini terdapat 342 siswa dari siswa kelas X SMA Cahaya Medan sebagai populasi. Teknik pengambilan sampel proportionate stratified random sampling yang digunakan pada penelitian ini. Dalam penelitian ini sampel yang digunakan adalah pelajar SMA Cahaya Medan yang berjumlah 177 orang berdasarkan ketentuan yang diberikan oleh tabel Isaac dan Michael dengan taraf kesalahan 5\%.

Tabel I.

Tabel Sampel

\begin{tabular}{|c|c|c|c|}
\hline Kelas & $\begin{array}{l}\text { Jumlah } \\
\text { Siswa }\end{array}$ & $\begin{array}{l}\text { Sampel (Populasi kelas/jumlah } \\
\text { populasi keseluruhan } x \text {, jumlah } \\
\text { sampel yang ditentukan) }\end{array}$ & Persentase \\
\hline$\overline{X-I P A ~ I ~}$ & 42 & $42 / 342 \times 177=21,7=22$ Siswa & $12,42 \%$ \\
\hline X -IPA 2 & 42 & $42 / 342 \times 177=21,7=22$ Siswa & $12,42 \%$ \\
\hline X -IPA 3 & 42 & $42 / 342 \times 177=21,7=22$ Siswa & $12,42 \%$ \\
\hline X -IPA 4 & 42 & $42 / 342 \times 177=21,7=22$ Siswa & $12,42 \%$ \\
\hline X -IPS I & 42 & $42 / 342 \times 177=21,7=22$ Siswa & $12,42 \%$ \\
\hline$X-I P S 2$ & 42 & $42 / 342 \times 177=21,7=22$ Siswa & $12,42 \%$ \\
\hline$X-I P S 3$ & 42 & $42 / 342 \times 177=21,7=22$ Siswa & $12,42 \%$ \\
\hline$X-I P S 4$ & 43 & $43 / 342 \times 177=22,56=23$ Siswa & $13,06 \%$ \\
\hline Total & 342 & I77 Siswa & $100 \%$ \\
\hline
\end{tabular}

Penelitian ini menerapkan metode pembagian skala dalam mengukur kecerdasan moral serta pola asuh dengan setiap aspek kecerdasan moral yang disajikan oleh Lennick dan Kiel (dalam Endang, 20l8) yaitu meliputi; integritas, tanggung jawab, perasaan iba, pemaaf, yang masing-masing terdapat 6 aitem favourable dan 6 aitem unfavourable. Aspek-aspek pola asuh yang dikemukakan oleh Hurlock (dalam Ayu, 2016) yaitu; Pola asuh demokratis yang merupakan control orang tua kepada anak terhadap tuntutan dan keinginan orang tua yang bersifat rasional, fleksibel, dan disiplin. Aitem yang digunakan berjumlah 8 aitem fafourable dan 8 aitem unfavourable. Aspek pola asuh permisif yang meliputi ketidak perdulian terhadap anak, kontrol 
terhadap anak, pengabaian keputusan, serta pemberian nasehat kepada anak. Jumlah aitem yang digunakan 8 aitem favourable dan 8 aitem unfavourable.

Peneliti melakukan uji coba ataupun try out terlebih dahulu sebelum melakukan penelitian. Try out dilakukan terhadap subjek yang sesuai dengan karakteristik yang di minta untuk penelitian di SMA Cahaya Medan. Jumlah subjek dalam uji coba ini yaitu sebanyak 80 siswa. Hasil uji validitas skala kecerdasan moral tersebut menunjukkan bahwa nilai $r$ berada pada angka 0.387 hingga 0.822 . Hal ini mengakibatkan sebanyak 8 aitem dinyatakan gugur. Total aitem yang digunakan untuk mengukur kecerdasan moral ini sebanyak 40 aitem. Untuk nilai uji Reliabilitas. Skala Kecerdasan moral tersebut dapat digunakan sebagai alat pengumpulan data dalam penelitian ini, karena pada uji Realiabilitas Skala Kecerdasan Moral yang menggunakan teknik Alpha Cronbach menunjukkan hasil $\alpha=0.978$.

Pada hasil uji Validitas yang terdapat pada Skala Pola asuh demokratis memperlihatkan bahwa nilai $r$ berada pada angka 0.335 hingga 0.724 dengan tidak terdapat aitem yang gugur sehingga seluruh jumah aitem yang digunakan dalam mengukur pola asuh demikratis pada penelitian ini sebanyak 16 aitem. Skala pola asuh demokratis juga dapat di gunakan karena dinilai layak dengan hasil $\alpha=0.908$ yang dilihat melalui teknik Alpha Cronbach untuk melihat Reliabilitas skala ini sebagai pengumpulan data penelitian.

Uji validitas terhadap Skala Pola asuh otoriter memperlihatkan bahwa nilai $r$ bergerak dari angka 0.659 hingga 0.749. Dengan ini dapat dilihat bahwa sebanyak 6 aitem dinyatakan gugur sehingga jumlah aitem yang dipakai untuk mengukur pola asuh otoriter sebanyak 10 aitem.

Hasil dari Reliabilitas Skala pola asuh otoriter ini yaitu $\alpha=0.933$ yang di uji dengan menggunakan teknik Alpha Cronbach. Untuk itu dapat disimpulkan bahwa skala pola asuh otoriter dapat digunakan sebagai alat pengumpulan data penelitian.

Pada uji validitas Skala Pola asuh Permisif tidak terdpat aitem yang gugur karena dilihat melalui nilai $r$ yang bergerak dari angka 0.426 hingga 0.994 . Sehingga jumlah aitem yang dipakai sebanyak 16 aitem. Teknik Alpha Cronbach digunakan juga untuk melihat Reliabilitas Skala pola asuh permisif yang menyimpulkan bahwa skala Pola asuh permisif layak digunakan sebagai alat pengumpulan data penelitian dengan hasil $\alpha$ $=0.989$.

Setelah diketahui bahwa hasil uji validitas dan reliabilitas yang digunakan adalah baik, peneliti kemudian menyebarkan angket kepada siswa yang menjadi subyek penelitian ini yaitu sebanyak 177 siswa. Setelah data terkumpul, selanjutnya peneliti melakukan pengolahan data dan juga uji hipotesis dengan menggunakan teknik analisis regresi berganda. Pengolahan data dan juga uji hipotesis penelitian ini menggunakan bantuan Statistic 23 for Windows (SPSS 23).

\section{Hasil}

Penelitian dilakukan terhadap 177 orang siswa- siswi SMA Cahaya Medan. Pengambilan data berawal dengan membagikan skala penelitian dengan satu set eksemplar berupa booklet, terdiri dari 2 (dua) skala yaitu skala kecerdasan moral dan skala pola asuh.

Tabel 2.

Data Deskriptif Kecerdasan Moral dan Pola asuh

\begin{tabular}{lllll}
\hline & Kecerdasan & \multicolumn{3}{c}{ Pola asuh } \\
\cline { 3 - 5 } & Moral & Demokratis & Otoriter & Permisif \\
\hline Skor Minimum & 93 & 32 & 18 & 23 \\
Skor Maksimum & 146 & 57 & 35 & 45 \\
Skor Rata-rata & 118.30 & 48.14 & 26.48 & 32.55 \\
Standar Deviasi & 10.75 & 4.925 & 3.152 & 4.174 \\
Kategori Rendah (Persentase) & $0(0 \%)$ & $2(1.12 \%)$ & $6(3.3 \%)$ & $80(45.2 \%)$ \\
Kategori Sedang (Persentase) & $103(58.1 \%)$ & $89(50.28 \%)$ & $154(87.0 \%)$ & $97(54.80 \%)$ \\
Kategori Tinggi (Persentase) & $74(41,9 \%)$ & $86(48.6 \%)$ & $17(9.70 \%)$ & $0(0 \%)$ \\
\hline
\end{tabular}


Berdasarkan data pada tabel 2, tidak terdapat subyek (0\%) yang memiliki kecerdasan moral rendah pada variabel kecerdasan moral, 103 subyek dengan (58.1\%) memiliki kecerdasan moral sedang dan 74 subyek (41.9\%) memiliki kecerdasan moral tinggi. Berdasarkan penjelasan yang telah dipaparkan di atas peneliti menyimpulkan bahwa rata-rata subyek penelitian memiliki kecerdasan moral yang sedang.

Diperoleh mean empiric sebesar II8.30 dari skala kecerdasan moral yang telah diisi oleh subyek dengan standar deviasi 10.75 . Apabila mean hipotetik < mean empiric maka hasil penelitian yang diperoleh akan dinyatakan tinggi dan sebaliknya jika mean hipotetik $>$ mean empiric maka hasil penelitian akan dinyatakan rendah. Hasil analisis untuk skala kecerdasan moral diperoleh mean hipotetik < mean empiric yaitu $100<$ I I8.30 maka peneliti menyimpulkan bahwa kecerdasan moral pada subyek penelitian lebih tinggi dari pada populasi padaumumnya.

Selanjutnya, untuk hasil kategorisasi pola asuh demokratis, menujukkan bahwa terdapat 2 subyek (I.I2\%) dari 177 subyek yang memiliki pola asuh demokratis rendah, dan 89 subyek $(50.28 \%)$ memiliki pola asuh demokratis sedang juga terdapat 86 subyek (48.6\%) yang memiliki pola asuh demokratis tinggi. Dengan penjelasan di atas maka disimpulkan bahwa rata-rata subyek penelitian memiliki pola asuh demokratis yang sedang. Dari skala pola asuh yang diisi subyek, maka diperoleh mean empiric sebesar 48.14 dengan standar deviasi 4.925. Apabila mean empiric > mean hipotetik maka hasil penelitian yang diperoleh akan dinyatakan tinggi dan sebaliknya jika mean empiric < mean hipotetik maka hasil penelitian akan dinyatakan rendah. Hasil analisis untuk skala pola asuh demokratis diperoleh meanempiric > mean hipotetik yaitu 48. I4 > 40 maka peneliti menyimpulkan bahwa pola asuh demokratis pada subyek penelitian lebih tinggi dari pada populasi pada umumnya.

Hasil kategorisasi pola asuh otoriter dari 177 subyek, menujukkan bahwa terdapat 6 subyek (3.3\%) yang memiliki pola asuh otoriter rendah, I54 subyek (87.0\%) memiliki pola asuh otoriter sedang dan 17 subyek (9.70\%) yang memiliki pola asuh otoriter tinggi. Berdasarkan penjelasan di atas disimpulkan bahwa ratarata subyek penelitian memiliki pola asuh otoriter yang sedang.

Dari skala pola asuh yang diisi subyek, diperoleh mean empiric sebesar 26.24 dengan standar deviasi 3.I52. Apabila mean hipotetik < mean empiric maka hasil penelitian yang diperoleh akan dinyatakan tinggi dan sebaliknya jika mean hipotetik $>$ mean empiric maka hasil penelitian akan dinyatakan rendah. Dari hasil analisis untuk skala pola asuh otoriter diperoleh mean empiric > mean hipotetik yaitu $26.24>25$ disimpulkan bahwa pola asuh otoriter pada subyek penelitian lebih tinggi dari pada populasi padaumumnya. Kategorisasi pada pola asuh permisif dari 177 subyek, terdapat 80 subyek (45.2\%) yang memiliki pola asuh permisif rendah, 97 subyek (54.80\%) memiliki pola asuh permisif sedang dan tidak terdapat subyek yang memiliki pola asuh permisif tinggi. Penjelasan di atas dapat disimpulkan bahwa ratarata subyek penelitian memiliki pola asuh permisif yang sedang.

Dari skala pola asuh yang diisi subyek, diperoleh mean empiric sebesar 32.55 dengan standar deviasi 4.I74. Apabila mean empiric $>$ mean hipotetik maka hasil penelitian yang diperoleh akan dinyatakan tinggi dan sebaliknya jika mean empiric < mean hipotetik maka hasil penelitian akan dinyatakan rendah. Hasil analisis untuk skala pola asuh otoriter diperoleh mean empiric > mean hipotetik yaitu $32.55>40$ maka disimpulkan pola asuh permisif pada subyek penelitian lebih tinggi daripada populasi padaumumnya.

Setiap variabel penelitian telah terdistribusi secara normal atau tidak dapat diketahui dari hasil uji normalitas sebaran yang dilakukan. Uji normalitas sebaran yang digunakan dalam penelitian ini yaitu uji One-Sample Kolmogorov Smirnov Test. Jika $p>0.05$ data dikatakan normal (Priyatno,20I3). Hasil yang diperoleh yaitu koefisien KS-Z (Test Statistic) = 0.06I dengan sig. sebesar 0.200 untuk uji 2 (dua) ekor ( $p>$ 0.05), yang berarti bahwa nilai residual terdistribusi secaranormal.

Uji multikolinearitas dilakukan untuk menguji apakah dalam model regresi terjadi hubungan linear yang sempurna atau mendekati sempurna antar dua variabel idependen atau lebih (Priyatno, 20l3). Hal ini dilakukan dengan melihat nilai tolerance dan nilai variance inflation factor (VIF) dengan kriteria jika nilai tolerance $>0$, I atau nilai VIF < I,0 berarti tidak terjadi multikolinearitas. Hasil uji tersebut yang diperoleh nilai VIF dari pola asuh demokratis adalah I.I45, nilai VIF dari pola asuh otoriter adalah I.190, dan nilai VIF dari pola asuh permisif adalah I.245. Dengan ini membuktikan bahwa VIF $<10$, maka tidak terjadi korelasi antar variabel bebas yang signifikan.

Tujuan dari uji autokorelasi adalah untuk mengetahui apakah dalam model regresi linear terjadi korelasi 
residual untuk pengamatan satu dengan pengamatan lain yang disusun menurut runtun waktu (Priyatno,2013). Hasil yang diperoleh dari uji tersebut diperoleh nilai statistik Durbin- Watson 2.015 terletak diantara 1.7886 dan $2.21 \mathrm{I}$, maka tidak terjadi autokorelasi.

Pengujian heteroskedastisitas dapat menggunakan teknik uni koefisien korelasi spearman's rho, yaitu mengorelasikan variabel independen dengan residualnya. Apabila antara variabel independen dengan residual diperoleh signifikansi lebih dari 0.05 maka tidak terjadi heteroskedastisitas (Priyatno,20I3). Hasil yang diperoleh dari uji tersebut adalah pola asuh demokratis $(p=0.37 \mathrm{I})$, pola asuh otoriter $(p=0.575)$ dan pola asuh permisif $(\mathrm{P}=0.554)$ adalah lebih besar dari 0.05 , maka tidak terjadi heteroskedasitas.

\section{Hasil Uji Hipotesis}

\section{a. Hipotesis Mayor}

Tidak terdapat hubungan antara kecerdasan moral dengan pola asuh yang dinyatakan dengan nilai $\mathrm{F}=$ 2.646 dan $\mathrm{p}=0.05 \mathrm{I}(\mathrm{p}>0.05)$ dari hasil regresi diperoleh hasil hipotesa mayor, namun nilai Adjusted $R$ Square $=0.027$ yang berarti pola asuh demokratis, otoriter dan permisif memberikan sumbangan efektif sebesar 2,7 persen terhadap kecerdasan moral dan sisanya 97,3 persen dipengaruhi oleh faktor lain yang tidak diteliti.

\section{b. Hipotesis Minor}

Hasil analisis dari hipotesis minor dapat simpulkan bahwa: Terdapat hubungan positif antara pola asuh demokratis dengan kecerdasan $=$ moral dengan nilai $p=0.040(p<0.05)$ dan $r=0.156$ yang berarti hipotesis diterima. Tidak terdapat hubungan negatif antara pola asuh otoriter dengan kecerdasan moral dengan nilai $p=0.167(p>0.05)$ dan $r=0.105$ yang berarti hipotesis ditolak. Tidak terdapat hubungan negatif antara pola asuh permisif dengan kecerdasan moral dengan nilai $p=0.570(p>0.05)$ dan -0.043 yang berarti hipotesis ditolak.

\section{Tabel 4.}

Hasil Analisis Nilai $r$ Korelasi

\begin{tabular}{lll}
\hline Jenis Pola asuh & Sig. & Correlation Partial \\
\hline Demokratis & 0.040 & 0.156 \\
Otoriter & 0.167 & 0.105 \\
Permisif & 0.570 & -0.043 \\
\hline
\end{tabular}

\section{Pembahasan}

Diperoleh hasil penelitian, pada 177 orang siswa-siswi SMA Cahaya Medan bahwa pernyataan hipotesis mayor yang berbunyi adanya hubungan antara pola asuh dengan kecerdasan moral ditolak dengan nilai $\mathrm{F}=$ 2.646 dan $p=0.051$ ( $p>0.05)$ dengan Adjusted $R$ Square $=0.027$. Penelitian ini sejalan dengan penelitian yang dilakukan oleh Ahsan, Susmarini, Anitasari (2014) yaitu tidak terdapat hubungan yang signifikan antara pola asuh dengan tingkat kecerdasan moral dengan nilai $p=0.053(p>0.05)$

Hasil analisis dari hipotesis minor menyatakan bahwa hubungan antara pola asuh demokratis dengan kecerdasan moral adalah terdapat hubungan positif dengan nilai $p=0.040(p<0.05)$, dapat dikatakan bahwa hipotesis diterima. Sejalan dengan penelitian yang dilakukan oleh Ahsan, Susmarini, Anitasari (20l4) bahwa 70 persen orang tua yang cenderung mengasuh anak dengan pola demokratis mempunyai anak yang memiliki tingkat kecerdasan moral yang baik. Pengasuhan secara demokratis yang diberikan kepada anak misalnya menghargai kebebasan anak sebagai individu, fleksibel, penetapan tuntutan yang bersifat rasional dan mengutamakan kedisiplinan anak dengan kontrol yang baik dari orang tua sungguh membantu anak melakukan perbuatan - perbuatan yang mengarah kepada moral yangbaik.

Wintoro dan Wahyuni (2019) dalam penelitiannya sebanyak 21 responden $(63,6 \%)$ anak yang memiliki perkembangan moral yang baik karena di asuh dengan pola demokratis. Terbentuknya moral seorang anak, baik tidaknya moral seorang anak tidak terlepas dari stimulus-stimulus yang diberikan orang tua, juga bagaimana orang tua memperlakukan anak, mendidik, membimbing dan mendisiplinkan serta melindungi anak dalam menggapai proses kedewasaan sampai dengan membentuk perilaku anak sesuai dengan norma 
dan nilai yang baik yang sesuai dengan kehidupanmasyarakat.

Hasil penelitian yang dilakukan oleh Rottie,J., \& Karundeng (2016) juga sejalandengan penelitian ini dimana ada hubungan positif antara pola Asuh Orang tua dengan Kecerdasan Moral Anak. Kebiasaan mendengarkan pendapat anak bahkan berbincang dengan anak mengenai seggenap kebutuhan, kegiatan sehari-hari membantu anak untuk melakukan perilaku-perilaku yang baik dalam hidup setiaphari.

Hasil yang diperoleh dari hipotesis minor yaitu tidak terdapat hubungan negatif antara pola asuh otoriter dan permisif dengan kecerdasan moral yang dinyatakan dengan nilai $p=0.167(p>0.05)$ dan $p=0.570(p$ $>0.05$ ), maka dapat dinyatakan hipotesis ditolak. Hal ini sejalan dengan hasil penelitian yang dilakukan oleh Winasih \& Maksum (2017) bahwa terdapat 3 orang (6.52\%) anak yang mengalami pola asuh otoriter menunjukkan perkembangan moral yang kurang, dan penelitian yang dilakukan oleh Ahsan, Susmarini, Anitasari (2014) yang mengatakan bahwa terdapat $5 \%$ anak dengan pola asuh permisif memiliki tingkat kecerdasan moral yang tidak baik. Anak yang selalu menekan atau mengekang pendapat dan keinginannya dan tidak diberi kesempatan untuk mengungkapkannya dimana orang tua yang selalu memberikan perintah dan mengatur segala kebutuhan dan perilaku anak maka anak cenderung untuk tidak menyatakan diri yang sebenarnya sehingga ketika tidak berada dalam pengawasan orang tua anak akan melakukan perilakuperilaku yang tidak sesuai dengan moral yang baik. Demikian juga dengan anak yang dibiarkan dengan bebas oleh orang tua tanpa kontrol yang baik, membiarkan anak melakukan apasaja yang diinginkannya. Anak yang mengalami pola pengasuhan seperti ini jarang bahkan tidak mendapat teguran bila melakukan hal-hal yang tidak baik sehingga ketika ia ingin melakukan perbuatan tidak baik sekalipun ia tidak merasa takut karena tidak mempunyai kontrol yang baik dari orang tua dan menganggap hal itu sebagai sesuatu hal yang biasa bahkan untuk menyatakan kehebatannya.

Berdasarkan penjelasan diatas disimpulkan terdapat hubungan positif antara pola asuh demokratis dengan kecerdasan moral dan tidak terdapat hubungan negatif antara pola asuh otoriter dan permisif dengan kecerdasan moral. Penelitian ini juga membuktikan bahwa asuhan orang tua terhadap anak dengan menggunakan pola yang berbeda-beda menghasilkan kecerdasan moral yang berbeda yang artinya anak yang diasuh dengan pola demokratis yang tinggi memiliki kecerdasan moral yang tinggi.

Berdasarkan hasil observasi yang dilakukan peneliti terhadap subyek yang mengalami pola asuh demokratis adalah mereka mengerjakan tugas-tugas dengan tepat waktu, tidak pernah terlambat masuk kelas, dan bertutur kata dengan sopan, ramah dan bila menemukan kesulitan dalam pelajaran mereka bertanya dengan santun kepada guru pengampu mata pelajaran tersebut. Mereka juga menghargai sesama teman dengan baik.

Hasil observasi yang dilakukan terhadap anak-anak yang diasuh dengan pola asuh otoriter diperoleh hasil sebagai berikut mereka jarang bercanda dengan teman sebaya, jarang senyum, dan apabila terdapat materi belajar yang belum dimengerti dan belum memahami maksud tugas yang diberikan guru, beberapa diantara mereka ada yang sampai merasa tertekan karena bila memperoleh nilai jelek dalam mengerjakan tugas tersebut akan mendapat hukuman dari orang tua. Sedangkan mereka yang mengalami pola asuh permisif bersikap tidak perduli dengan segala peraturan seperti membayar biaya pendidikan tidak tepat waktu, mengumpulkan tugas tidak pada waktunya, membuat kegaduhan di dalam kelas.

Hasil wawancara terhadap siswa yang diasuh dengan pola asuh demokratis dimana orang tua mendengarkan dan memberikan kesempatan kepada anak untuk menyampaikan pendapat dan diberikan arahan yang positif menunjukkan sikap empati yang tinggi terutama bila teman dalam keadaan susah mereka diajar untuk senasib dan berempati, mampu untuk memaafkan siapa saja yang bersalah kepada mereka, tidak memilih- milih teman, bertanggungjawab dengan tugas apa saja yang diberikan kepada mereka dan memiliki integritas yang tinggi.

Hasil wawancara dengan anak yang diasuh dengan pola asuh otoriter atau permisif adalah mereka sering menunjukkan bahwa meskipun mereka dipaksa oleh orang tua dan dikekang, harus melaksanakan keinginan orang tua masih memiliki tanggung jawab, perasaan empati dan integritas.

\section{Kesimpulan}

Berdasarkan hasil analisa regresi pada hipotesis mayor membuktikan bahwa tidak ada hubungan antara pola asuh dengan kecerdasan moral dengan kata lain pola asuh memberikan kontribusi sebesar 2,7\% 
terhadap kecerdasan moral dan $\mathbf{9 7 , 3} \%$ sisanya dipengaruhi oleh factor lain yang tidak diteliti. Analisa regresi pada hipotesis minor menunjukkan bahwa: I) Ada hubungan positif antara pola asuh demokratis dengan kecerdasan moral. 2) Tidak ada hubungan negatif antara pola asuh otoriter dengan kecerdasan moral. 3) Tidak ada hubungan negatif antara pola asuh permisif dengan kecerdasan moral.

Implikasi penelitian ini bagi pihak sekolah, agar mengefektifkan bimbingan dan konseling sehingga membantu para siswa untuk memecahkan masalah yang dihadapi sehingga dapat meningkatkan kecerdasan moral yang tinggi. Bagi orang tua, agar kiranya sungguh memperhatikan anak sebagai peribadi yang patut dihargai, dididik, dibimbing, diasuh dengan pola yang baik sehingga moral anak terbentuk dengan baik. Bagi siswa-siswi sebagai subyek penelitian ini agar bersikap terbuka terhadap setiap bimbingan orang tua dan guru agar terbantu untuk meningkatkan kecerdasan moral yang baik dalam berperilaku. Bagi peneliti selanjutnya, kiranya dapat menemukan variabel lain yang dapat dihubungkan dengan kecerdasan moral.

\section{REFERENSI}

Ahsan,A; Susmarini,D; Adisantika,A; \& Anitasari, A, R. (20I4). Hubungan Antara Pola Asuh Orang Tua (lbu) Yang Bekerja Dengan Tingkat Kecerdasan Moral Anak Usia Prasekolah (4-5) Tahun di TK Mutiara Indonesia Kedungkandang Malang. Journal of Educational Innovation, 2 (2), $30-40$.

Arikunto (2006) Metode Penelitian Kualitatif. Jakarta. Bumi Aksara.

As'Ari, M, H (20I5). Hubungan antara pola asuh otoriter dengan kemandirian, (Skripsi Surakarta). Fakultas Psikologi, Universitas Muhammadiyah.

Ayu, D., \& Astuti (2016). Pola Asuh Orang Tua, Konsep Diri Remaja dan Perilaku Seksual.

Jurnal Ilmiah dan Penelitian Kesehatan ,I (I), I0-I7.

Azwar, S. (2012).Reliabilitas dan Validitas. Yogyakarta : Pustaka Pelajar.

Borba, M (2008). Membangun Kecerdasan Moral (Tujuh kebajikan utama agar anak bermoral tinggi).

Hasan (2004).Metodologi Research. Yogyakarta: Andi Offset.

Jannah, M., Yacob, F., \& Julianto (2017).Rentang kehidupan Manusia (Life Span Development) dalam Islam.International Journal of Child and Gender Studies, 3 (I), 97-I I4.

Kurniawan \& Yuniarto (2018) Analisis Regresi. Depok : Prenadamedia.

Maksum \& Winasih. (2017) Hubungan Pola Asuh Orang Tua terhadap Perkembangan Moral Siswa Kelas Tinggi di SD Negeri Cimpon Desa Tirtosari Kecamatan Kretek Kabupaten.LITERASI, Volume VIII, No. 2

Pangestu, K., Fadillah., \& Halida (2016). Hubungan Pola Asuh Ibu dan Kecerdasan Moral Anak Usia 5-6 tahun.Jurnal Pendidikan dan Pembelajaran, 5(9), I- I 2.

Priyatno. (20I3) Analisis Korelasi,regresi,dan Multivariate dengan SPSS. Yogyakarta: Gava Media.

Rahman, U., Mardhiah., \& Azmidar (2015). Hubungan Antara Pola Asuh Permisif Orang Tua Dan Kecerdasan Emosional Siswa Dengan Hasil Belajar Matematika.jurnal

Pendidikan Dasar Islam, 2(I), I I6-I30.

Rottie, J. \& Karundeng, M. (2016).Hubungan Pola Asuh Orang tua dengan Kecerdasan Moral Anak Usia I 2-I5 Tahun di SMP Negeri I Tabukan Kepulauan Sangihe.Ejournal Keperawatan(e-Kp), 4 (I), I-6 
Santrock, J.W. 20I I.Life-Span Development (Perkembangan Masa Hidup).Jakarta: Erlangga.

Shochib, M. (2010).Pola Asuh Orang Tua Dalam Membantu Anak Mengembangkan Disiplin Diri.Jakarta : Rineka Cipta

Stanislaus. (2006) Pedoman Analisis Data dengan SPSS Yogyakarta: Graha Ilmu

Sugiyono. (2010). Metode Penelitian Pendidikan Pendekatan Kuantitatif Kualitatif, dan R \&D

Bandung : Alfabeta.

Wintoro, Sri Wahyuni. (2019). Hubungan Pola Asuh Orang Tua Dengan Perkembangan Moral Anak Di Sd N 3 Buntalan Klaten Tengah, Klaten. Jurnal Involusi Kebidanan Vol. 9 No. 17

KPAI : Tawuran Pelajar 2018 Lebih Tinggi Dibanding Tahun lalu. ( 2018 : September) Metro.Tempo.

Diunduh dari

http://metro.tempo.co/read/I 125876/kpaitawuranpelajar20 I8lebihtinggidibandingtahunlalu/full\&view=ok tanggal 01 November 2018

Pengakuan Geng Motor Soal Motif Kekerasan Terhadap Korbannya. (2019 : Februari) Metro.Tempo. Diunduh dari https://metro.tempo.co/read/II775/4/pengakuan-geng-motor-soalmotifkekerasanterhadap-korbannya/full\&view=ok tanggal 22 Februari 2019 